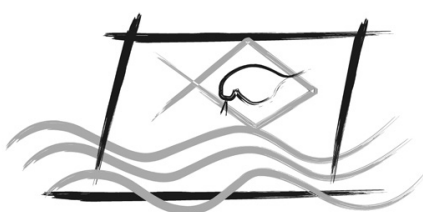

ECOTOX - BRASIL

\title{
Study of the occurrence of agrochemicals in the waters of the Marombas River- Santa Catarina - Brazil
}

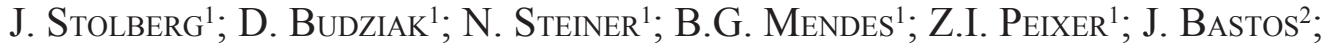 \\ D.R. Scharf ${ }^{2}$; E.L. Simionatto ${ }^{2} \&$ R. Geremias ${ }^{3}$ \\ ${ }^{1}$ Campus Curitibanos, Federal University of Santa Catarina, Curitibanos, Santa Catarina, Brazil \\ ${ }^{2}$ Laboratory of Chromatography, Foundation of the University of Blumenau, Blumenau, Santa Catarina, Brazil \\ ${ }^{3}$ Campus Araranguá, Federal University of Santa Catarina, Rodovia Governador Jorge Lacerda, 3201, \\ Araranguá, Santa Catarina, Brazil, CEP 88900-000
}

(Received March 20, 2015; Accept July 06, 2015)

\begin{abstract}
The region of the sub-basin of the Marombas River is based on economic agroforestry activities. These activities use agrochemicals that can contaminate surface and groundwater and cause diseases in humans and animals. The present study aimed to detect the presence of agrochemicals in the waters of the Marombas River at 4 different points. The water samples were collected every two months over a 1-year period. The concentrations of carbamates, herbicides, fungicides and organophosphates were analyzed. The chromatographic analysis revealed the presence of the fungicide Azoxystrobin $(0.65 \mu \mathrm{g}$ $\mathrm{L}^{-1}$ ) in the water sample collected at a point in the river with a strong influence of agricultural activities. The concentration of other agrochemicals was below the detection limit of the assay methods used at all points, and in all types of sampling. The Marombas River is subject to contamination by agrochemicals, which represents a potential risk to the human population and to the aquatic biota.
\end{abstract}

Keywords: Agrochemicals, azoxystrobin, Marombas River, contamination, chromatography.

\section{INTRODUCTION}

Contamination of water by agrochemicals has been recognized as a major source of contamination worldwide, due to their potential toxicity to humans and animals. They are known to be carcinogenic, mutagenic, teratogenic, inhibitors of the acetylcholinesterase enzyme, and resistant to destruction in the environment (Braun et al., 2012; Conceição \& Protti, 2012; Carvalho et al., 2013; Mostafalou \& Abdollahi, 2013; Simioni, 2013; Franco-Bernardes et al., 2014). Brazil is one of the world's main agrochemicals markets, selling more than 235 thousand tons of these products in 2009. Brazil's consumption of agrochemicals and related chemicals (tons of active ingredients) increased by $13.7 \%$ between 2005 and 2009 , while the acreage of major crops increased by only
$1.76 \%$. Among the regions of Brazil, the South had the second highest consumption, with approximately 72 thousand tons in 2009 (SIDRA, 2014). The Marombas River is located in the highlands of the state of Santa Catarina, southern Brazil, and is part of the Uruguay River basin. The waters of this river are used for municipal public supply in the region. This subbasin is located within the limits of an outcrop of volcanic rock in the Serra Geral, and also within the sandstone of the Botucatu formation, where there is a large underground water reservoir known as the Guarani Aquifer (Freitas et al., 2003). The population of the area $(80 \%$ urban) is approximately 156,000 inhabitants, distributed in small and medium-sized towns, only two of which have a population in excess of 30,000 inhabitants (IBGE, 2010). In the Marombas River drainage sub-basin region, economic activities have developed which are linked to the production systems of consumers

*Corresponding author: Reginaldo Geremias; e-mail: reginaldogeremias@gmail.com 
of agrochemicals and the like; to agriculture for temporary crops, such as soybeans, corn, beans, garlic and onions; and to permanent crops, such as apples, peaches and grapes. There are also forest-based economic activities, especially pine and eucalyptus harvesting used in forestry industries, as well as manufacturing and papermaking. The use of insecticides, fungicides or herbicides in the sub-basin poses the potential risk of contaminating surface water and harming the human populations that consume these waters and its aquatic organisms. The groundwater in the Botucatu and Serra Geral formations is also vulnerable to contamination because its exploitation takes place in relatively shallow wells, with recharge areas which reach the surface or wetlands and rivers (Scheibe \& Hirata, 2008).

Although the Marombas River is subject to contamination by agrochemicals, there have been few studies on the quality of its waters and the potential toxic exposure to biota. In this context, the evaluation of the presence of chemicals such as carbamates, herbicides, fungicides and organophosphates proposed in this study is of great importance for assessing the water quality and providing information on preserving water resources in this region of the country.

\section{MATERIALS AND METHODS}

The water samples used to determine the quantities of agrochemicals $(5 \mathrm{~L})$ were collected using borosilicate bottles refrigerated $\left(4^{\circ} \mathrm{C}\right)$ in a depth of $0.5 \mathrm{~m}$ along the Marombas River (Santa Catarina state, Brazil) over a 1-year period: April (S1), June (S2), August (S3), October (S4), December 2011 (S5) and March 2012 (S6) at 4 different Points (P), P1, P2, P3 and P4 (Figure 1), with a total of 24 samples. All the selected points of the Marombas River are in remote areas where sewage and wastewater are released, or urban centers. The sampling locations were: P1 $\left(27^{\circ} 12^{\prime} 56.0^{\prime \prime} \mathrm{S} ; 50^{\circ} 27^{\prime}\right.$ $58.3^{\prime} \mathrm{W}$ ), which corresponds to the region of the headwaters of the river; P2 (27 $12^{\prime} 07.08^{\prime \prime} \mathrm{S}$; $\left.50^{\circ} 38^{\prime} 05.5^{\prime} \mathrm{W}\right)$, located upstream of the water catchment point for public supply; P3 $\left(27^{\circ} 19^{\prime} 01.2^{\prime}\right.$ ' $\left.\mathrm{S} ; 50^{\circ} 45^{\prime} 47.5^{\prime} \mathrm{W}\right)$, located downstream in a

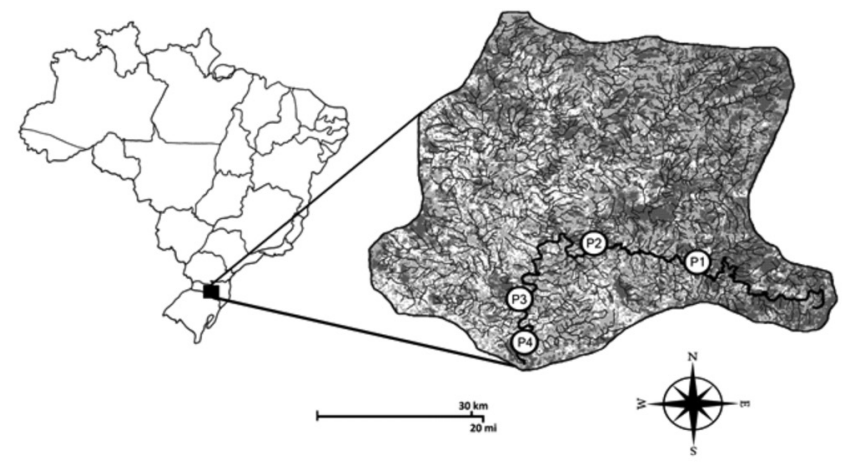

Figure 1- Collection points in the waters of the Marombas River and land use: agriculture $(\circ)$, pastures and fields $(\bullet)$; forests and reforestation $(\bullet)$ (Souza et al., 2012, adapted) major tributary; and P4 (27 24' 03.9'” S; 50 46' 10.6”' W), located near the confluence with the Canoas River.

Information related to land use and dimensions of the subbasin was obtained from the System Maps for Web Floristic Forest Inventory Santa Catarina (Souza et al., 2012) and the estimated percentage areas were obtained from images, using Adobe Photoshop CS5 ${ }^{\circledR}$. All other chemicals and solvents used for the extraction and isolation were of analytical grade. Hexane Toluene and Methanol were purchased from Vetec (Rio de Janeiro, Brazil), Dichloromethane from Exxodo Científica (São Paulo, Brazil) and Acetonitrile from Sigma Aldrich (Bellefonte, USA). The mix of carbamate compounds included: Aldicarbe; Aldicarb Sulfone; Aldicarb Sulfoxide; Carbofuran; Carbaryl; 3-Hydroxycarbofuran; Methiocarb; Methomyl; Oxamyl and Propoxur. Herbicides and fungicides: Atrazine; Cialotrin; Diuron; Metalaxyl-M; Metconazole; Metconal; Tebuconazole and Azoxystrobin. Organophosphates: Dimethoate; Disulfoton; Famphur; Parathion Ethyl; Parathion Methyl; Phorate; O,O,O-Triethyl Phosphorothioate; Thionazin and Sulfotep. All the standard mixtures were purchased from Supelco Analytical (Bellefonte, USA). The chromatographic analysis of carbamates, fungicides and herbicides was performed by High Performance Liquid Chromatography (HPLC, Varian Star Pro-310, CA,USA with UV detection, using a $\mathrm{C} 18$ ChromSpher5 column, $250 \mathrm{~mm}$ x $4.6 \mathrm{~mm}$, for the separation of compounds, CA,USA). For the carbamates, the solvent mixture used for elution was initially $18 \% \mathrm{CH}_{3} \mathrm{CN}: 82 \% \mathrm{H}_{2} \mathrm{O}$, reaching $65 \% \mathrm{CH}_{3} \mathrm{CN}: 35 \% \mathrm{H}_{2} \mathrm{O}$ over a gradient of 15 minutes and $100 \% \mathrm{CH}_{3} \mathrm{CN}$ over a gradient of 15 to 20 minutes. The flow used was $2 \mathrm{~mL} \mathrm{~min}^{-1}$ and the reading was made at $214 \mathrm{~nm}$. The fungicide/herbicide mixture of solvents used for elution was initially $30 \% \mathrm{CH}_{3} \mathrm{CN}$ : $70 \%$ $\mathrm{H}_{2} \mathrm{O}$ for the first 3 minutes, with a gradient from 3 to 25 minutes with $100 \% \mathrm{CH}_{3} \mathrm{CN}$ and an isocratic period of 25 to 30 minutes with $100 \% \mathrm{CH}_{3} \mathrm{CN}$ at a flow rate of $1 \mathrm{~mL} \mathrm{~min}^{-1}$ and reading at $214 \mathrm{~nm}$. Organophosphate agrochemicals were analyzed by gas chromatography coupled with mass spectrometry (GC/ MS; CP3800 Varian and Varian Saturn 2000, CA, USA). All separations were performed on an OV5 capillary column (30 $\mathrm{mx} 0.25 \mathrm{~mm}$ id, film thickness $0.25 \mathrm{mM}$ ). Helium was used as the ultra-pure carrier gas and make-up (auxiliary) in constant flow $\left(1 \mathrm{ml} \mathrm{min}^{-1}\right)$. The temperature program ranged from $80^{\circ} \mathrm{C}$ (held for $2 \mathrm{~min}$ ) to $250^{\circ} \mathrm{C}$ at a rate of $10^{\circ} \mathrm{C} \mathrm{min}^{-1}(11 \mathrm{~min}$ ). In all analyses, the injector temperature was $250^{\circ} \mathrm{C}$. The limits of detection (LD) were defined as three times the signal-to-noise ratio, and the limits of quantification (LQ) were defined as ten times the signal-to-noise ratio. The organophosphate ranges of 0.05 to $1.82 \mathrm{ug} \mathrm{L}^{-1}$ and 1.67 to $6.06 \mathrm{ug} \mathrm{L}^{-1}$ were obtained from $L D$ and $L Q$, respectively. For carbamates, the $L D$ range was $0.01-0.13 \mathrm{ug} \mathrm{L}^{-1}$ and the LQ range $0.03-0.4 \mathrm{ug} \mathrm{L}^{-1}$. For herbicides and fungicides, the LD range was $0.01-0.08 \mathrm{ug}$ $\mathrm{L}^{-1}$ and the LQ range $0.03-0.27 \mathrm{ug} \mathrm{L}^{-1}$. Distilled water was used as a blank. The analysis of agrochemicals was performed following the protocols of the Environmental Protection Agency of the United States (USEPA) and the International Organization for Standardization (ISO). The stock solution concentration for each class of pesticide compound was 
prepared with $20 \mathrm{ug} \mathrm{ml}^{-1}$ (hexane:toluene, 1:1) and carbamates were $100 \mathrm{ug} \mathrm{ml} l^{-1}$ (methanol). For all analyses, $1 \mathrm{~L}$ of the sample was used; the extraction was performed and repeated three times with $20 \mathrm{ml}$ of Dichloromethane and the solvent was evaporated in a rotary evaporator (Fisatom, São Paulo, Brazil). Then, $1 \mathrm{ml}$ of Dichloromethane was measured, except during the analysis of carbamates, when it was calibrated to $1 \mathrm{ml}$ with Acetonitrile. Calibration curves were obtained by external calibration involving a five point concentration ranging from 0.5 to $10 \mathrm{mg} \mathrm{L}^{-1}$.

\section{RESULTS AND DISCUSSION}

The results of the determination of agrochemicals in the waters of the Marombas River (Table 1) revealed the presence of Azoxystrobin (methyl (E) -2 - \{2 [6 - (2-cyanophenoxy) pyrimidin-4-yloxy] phenyl $\}-3$-methoxyacrylate) in samples collected at P3 during the month of August 2011.

The concentrations of other fungicides, herbicides, carbamates and organophosphates analyzed is shown to be below the detection limit of the assay methods employed at all points and during all sampling periods. Azoxystrobin is a broad-spectrum fungicide that belongs to the Strobilurin class, with aqueous solubility of $0.006 \mathrm{~g} \mathrm{~L}^{-1}\left(20^{\circ} \mathrm{C}\right)$, an octanol/water partition coefficient (Kow) of 2.5, an organic matter partition coefficient (Koc) of $500 \mathrm{~kg} \mathrm{~L}^{-1}$ and a half-life in the soil of 56 days (Komárek et al., 2010). Azoxystrobin is used to control diseases originating both in leaves and soil (Singh \& Singh, 2010). This fungicide is classified as highly toxic to aquatic organisms at a strength of less than $1 \mathrm{mg} \mathrm{L}^{-1}$ (Komárek et al., 2010). Azoxystrobin is considered to have low acute and chronic toxicity to humans, birds, mammals, and bees (Bartlett et al., 2002; EFSA, 2010). In the area of European

Table 1- Concentration of agrochemicals in the waters of the Marombas River at sampling point $3(\mathrm{P} 3)$

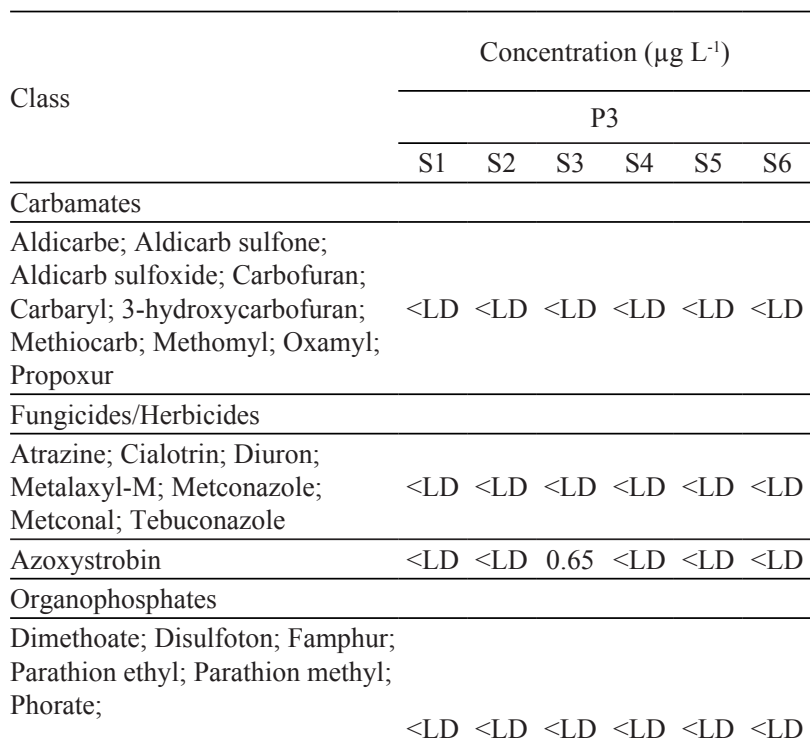

o,o,o-Triethyl phosphorothioate;

Thionazin; Sulfotep

$\mathrm{LD}=$ detection limit; $\mathrm{S}=$ sampling pesticide risk assessment, the EFSA (2010) concluded that Azoxystrobin and its formulations are highly toxic to aquatic organisms, potentially causing long-term adverse effects in the aquatic environment, and are considered dangerous. However, the most significant metabolites of Azoxystrobin in terms of environmental harmfulness were described as less toxic (EFSA, 2010). Azoxystrobin is toxic to freshwater and estuarine/marine fish and aquatic invertebrates, and instructions have been issued for ensuring that it does not contaminate lakes, streams, ponds, tidal marshes or estuaries (USEPA, 2009). Studies have reported that Azoxystrobin has toxic effects on fish, affecting mitochondrial respiration and the mechanisms that control cell growth and proliferation, as well as having genotoxic effects. It also has acute toxicity in Eisenia fetida and a toxic effect on bacteria, daphnia, algae, higher plants and amphibians. It has been proposed that R234886 ([(E)-2-(2-[6-cyanophenoxy)-pyrimidin-4yloxyl]-phenyl-3-methoxyacrylic acid]), the main product of Azoxystrobin degradation, should be investigated in monitoring programs for pesticides, also evaluating its ecotoxicological long-term effects (Cedergreen et al., 2006; Johansson et al., 2006; Bony et al., 2008; Gustafsson et al., 2010; Olsvik et al., 2010; Jørgensen et al., 2012; Wang et al., 2012). In Brazil, this fungicide is permitted for use in leaf applications on crops, such as garlic, citrus fruits, beans, figs, guava, corn, strawberries, peaches, soybeans, tomatoes and grapes (ANVISA, 2013). In the region of the Marombas River sub-basin, guided economic activities in agriculture, especially horticulture crops; garlic, tomatoes, beans, corn and soybeans, predominately use fungicides. Fungicides are widely used in the preventive control of garlic, which usually begins in late August in years with warm winters (winter being in June/July in the Southern hemisphere), or mid-September in years with cold winters. In the drainage area of the basin, estimated at around $4,000 \mathrm{~km}^{2}$, activities linked to agriculture make up $17 \%$ of the area, reforestation and forest $48 \%$ and pastures and fields $35 \%$ (Figure 1). In this distribution, in the regions around $\mathrm{P} 1$ and $\mathrm{P} 2$, there are lands with greater vegetation cover (forests and reforestation), while in the regions around $\mathrm{P} 3$ and $\mathrm{P} 4$, there is more agriculture, pastures and fields. In the work described by Mendes et al. (2011), contamination of the water of the Marombas River water by the agrochemicals Methomyl $\left(1.75 \mu \mathrm{g} \mathrm{L}^{-1}\right)$ and Metconazole $\left(4.98 \mu \mathrm{g} \mathrm{L}^{-1}\right)$ was also observed, which was believed to have come from the agricultural activity in the region. Thus, it can be suggested that the contamination of water by Azoxytrobin observed in our studies could be due to these crops.

\section{CONCLUSION}

In conclusion, the presence of agrochemicals found in the Marombas River represents a potential risk to the aquatic biota and human populations that use its waters. Therefore, proper management of chemicals in agroforestry activities in the sub-basin is required. It is also important to use farming methods that can reduce or eliminate the use of these compounds, contributing to the improvement of water quality 
for human consumption and the health of aquatic life. Finally, this work has a good contribution as an original study on the contamination of the Marombas River.

\section{ACKNOWLEDGMENTS}

This research was supported by grants from the Federal University of Santa Catarina, Brazil

\section{REFERENCES}

ANVISA (Agência Nacional de Vigilância Sanitária). 2013. Monografias de agrotóxicos: A26 - Azoxistrobina. http://portal.anvisa.gov.br/wps/wcm/connect/ c63732004d1a299d9e4efe4031a95fac/A26++Azoxistrobina. pdf?MOD=AJPERES. Accessed 13 Oct 2014.

BARTLETT, D.W., CLOUGH, J.M., GODWIN, J.R., HALL, A.A., HAMER, M. \& PARR-DOBRZANSKI, B. 2002. The strobilurin fungicides. Pest Manag Sci, 58: 647-662. http:// dx.doi.org/10.1002/ps.520

BONY, S., GILlET, C., BOUCHEZ, A., MARGOUM, C. \& DEVAUX, A. 2008. Genotoxic pressure of vineyard pesticides in fish: Field and mesocosm surveys. Aquat Toxicol, 89:197203. http://dx.doi.org/10.1016/j.aquatox.2008.06.017

CEDERGREEN, N., KAMPER, A. \& STREIBIG, J.C. 2006. Is prochloraz a potent synergist across aquatic species? A study on bacteria, daphnia, algae and higher plants. Aquat Toxicol, 78: 243-252. http://dx.doi.org/10.1016/j.aquatox.2006.03.007

EFSA (European Food Safety Authority). 2010. Conclusion on the peer review of the pesticide risk assessment of the active substance azoxystrobin. EFSA Journal, 8: 1542.

FREITAS, M.A., CAYE, B.R. \& MACHADO, J.L.F. 2003. Diagnóstico dos recursos hídricos subterrâneos do oeste do Estado de Santa Catarina; Projeto Oeste de Santa Catarina. CPRM/SDM-SC/SDA-SC/EPAGRI: Porto Alegre.

GUSTAFSSON, K., BLIDBERG, E., ELFGREN, I.K., HELLSTRÖM, A., KYLIN, H. \& GOROKHOVA, E. 2010. Direct and indirect effects of the fungicide azoxystrobin in outdoor brackish water microcosms. Ecotoxicology, 19: 431-44. http://dx.doi.org/10. 1007/s10646-009-0428-9

IBGE (Instituto Brasileiro de Geografia e Estatística). 2010. Atlas do censo demográfica 2010. <http://censo2010.ibge.gov.br/apps/ atlas/> Accessed 09 sep 2014

JOHANSSON, M., PIHA, H., KYLIN, H.\& MERILÄ, J. 2006. Toxicity of six pesticides to common frog (Rana temporaria) tadpoles. Environ Toxicol Chem, 25: 3164-3170.

JØRGENSEN, L.F., KJÆR, J., OLSEN, P. \& ROSENBOM, A.E. 2012. Leaching of azoxystrobin and its degradation product R234886 from Danish agricultural field sites. Chemosphere, 88: 554-562. http://dx.doi.org/10.1016/j.chemosphere.2012.03.027

KOMÁREK, M., CADKOVÁ, E., CHRASTNÝ, V., BORDAS, F. \& BOLLINGER, J.C. 2010. Contamination of vineyard soils with fungicide: A review of environmental and toxicological aspects. Environ Int, 36: 138-151. http://dx.doi.org/10.1016/j. envint.2009.10.005.

MENDES, B.G., BUDZIAK, D., STOLBERG, J., PEIXER, Z.I., DALMARCO J.B., SIMIONATTO, E.L., PEDROSA, R.C.,
FELIPE, K.B., OGAWA, J., PEGORARO, C., SCHEFFER, L., BESEN, M.R., OLIVEIRA, L. J. G.. G. \& GEREMIAS, R. 2011. Estudo da qualidade das águas do Rio Marombas (SC/ Brasil), utilizando parâmetros físico-químicos e bioensaios. Revista de Ciências Ambientais, 5: 43-58.

MOSTAFALOU. S. \& ABDOLLAHI, M. 2013. Pesticides and human chronic diseases: Evidences, mechanisms, and perspectives. Toxicol Appl Pharmacol, 268: 157-177. http:// dx.doi.org/10.1016/j.taap.2013.01.025.

OLSVIK, P.A., KROGLUND, F., FINSTAD, B. \& KRISTENSEN, T. 2010. Effects of the fungicide azoxystrobin on Atlantic salmon (Salmo salar L.) smolt. Ecotoxicol Environ Saf, 73: 1852-61. http://dx.doi.org/10.1016/j.ecoenv.2010.07.017

SCHEIBE, L.F. \& HIRATA, R.C.A. 2008. O contexto tectônico dos sistemas Aquífero Guarani e Serra Geral em Santa Catarina: uma revisão. In: Congresso Brasileiro de Águas Subterrâneas, 15, 2008, Natal - RN. Anais. São Paulo: ABAS.

SIDRA (Sistema IBGE de Recuperação Automática). 2014. Base de dados agregados. http://www.sidra.ibge.gov.br/bda/tabela/ listabll.asp? $=772 \& \mathrm{n}=0 \& \mathrm{u}=0 \& \mathrm{z}=\mathrm{p} \& \mathrm{o}=8 \& \mathrm{i}=\mathrm{P}$, Accessed 09 sep 2014

SIMIONI, F., SILVA D.F.N. \& MOTT, T. 2013. Toxicity of Glyphosate on Physalaemus albonotatus (Steindachner, 1864) from Western Brazil. Ecotoxicol Environ Contam, 8: 55-58 http://dx.doi.org/10.5132/eec.2013.01.008

SINGH, N. \& SINGH, S.B. 2010. Effect of moisture and compost on fate of azoxystrobin in soils. J Environ Sci Health B, 45: 676-81. http://dx.doi.org/10.1080/03601234.2010.502445

SOUZA, J.M., MARASCHIN, F., CARRIAO, S.L., ANTUNES, E.N. \& PINTO, E.S.P. 2012. Sistema de Mapas para a Web do Inventário Florístico Florestal de Santa Catarina. Epagri/Ciram. http://ciram.epagri.sc.gov.br/siffsc/. Accessed 16 Sep 2014.

USEPA (United States Environmental Protection Agency). 2009. Azoxystrobin. $\quad$ http://www.fao.org/fileadmin/templates/ agphome/documents/Pests_Pesticides/Specs/Azoxystrobin09. pdf. Accessed 24 Feb 2014.

WANG Y., WU, S., CHEN, L., WU, C., YU, R., WANG, Q. \& ZHAO, X. 2012. Toxicity assessment of 45 pesticides to the epigeic earthworm Eisenia fetida. Chemosphere, 88: 484-491. http://dx.doi.org/10.1016/j.chemosphere.2012.02.086

CONCEIÇÃO, M.B. \& PROTTI, B. L. 2012. Genotoxicity of Selected Pesticides in the Hen's Egg Test for Micronucleus Induction. J. Braz. Soc. Ecotoxicol, 7: 43-47 http://dx.doi. org/10.5132/jbse.2012.01.007

CARVALHO, S.J., MENEZES, M.S. \& GUIMARÃES, A.T.B. 2013. Analysis of Cholinesterase Enzyme Activity in Rineloricaria kronei from Coastal Rivers in Southern Brazil. Ecotoxicol Environ Contam, 8: 87-92. http://dx.doi.org/10.5132/ eec.2013.01.012

BRAUN, A.S., NOVELLI, A., VIEIRA1, B.H. \& ESPINDOLA1, E.L.G.. 2012. Ecotoxicological effects of Vertimec ${ }^{\circledR} 18 \mathrm{EC}$ on plankton. J Braz Soc Ecotoxicol, 7: 23-29 http://dx.doi. org/10.5132/jbse.2012.02.004

FRANCO-BERNARDES, M.F., MASCHIO, L.R., AZEREDOOLIVEIRA, M.T.V. \& ALMEIDA, E.A. 2014. Biochemical and genotoxic effects of a commercial formulation of the herbicide tebuthiuron in Oreochromis niloticus of different sizes. Ecotoxicol Environ Contam, 9: 59-67 http://dx.doi.org/10.5132/ eec. 2014.01.008 